\title{
The Effect of Partial Defoliation, Leaf Position and Developmental Stage of the Vine on the Photosynthetic Activity of Vitis vinifera L. cv Cabernet Sauvignon*
}

\author{
J.J. Hunter ${ }^{1)}$ and J.H. Visser ${ }^{2)}$ \\ Viticultural and Oenological Research Institute (VORI), Private Bag X5026, 7600 Stellenbosch, Republic of South Africa. \\ Botany Department, University of Stellenbosch, 7600 Stellenbosch, Republic of South Africa. \\ Submitted for publication: April 1988 \\ Accepted for publication: August 1988 \\ Key words: Vitis vinifera, Defoliation, Leaf position, Photosynthesis, Stomatal resistance, Transpiration, Leaf microclimate, Developmental \\ stages.
}

\begin{abstract}
The effect of partial defoliation, leaf position and developmental stage of the vine on the photosynthesis, stomatal resistance and transpiration of Vitis vinifera L. cv Cabernet Sauvignon was investigated.

Partially defoliated vines displayed a higher rate of photosynthesis, generally increasing with degree of defoliation. The highest photosynthetic rates were found for the apical leaves, while those of the leaves opposite and below the bunches were restricted. Generally, rate of photosynthesis declined as the season progressed.

The course of transpiration rate and stomatal resistance correlated with that of the rate of photosynthesis. However, transpiration and photosynthesis correlated poorly in the case of the apical leaves. In general, photon flux density and relative humidity at the leaf surface increased with an increase in defoliation percentage for all leaf positions. Leaf temperature was not significantly affected by partial defoliation.

The results of the investigation suggested that excess vegetative growth is detrimental to interior-canopy microclimate as well as the photosynthetic rate of the entire vine. Partial defoliation seemed to provide a means to reduce some of the deleterious effects of vigorous growth.
\end{abstract}

It is commonly observed that vegetative growth in South African vineyards tends to be excessively vigorous. This situation may result in poor canopy microclimate and eventually reduced grape quality (Smart, 1973; 1980; 1985; Koblet, 1977; 1984; Kliewer, 1980; Smart et al., 1985a, 1985b) and productivity (Shaulis, Amberg \& Crowe, 1966; May, Shaulis \& Lemon, 1982; Koblet, 1984).

Partial defoliation of Cabernet Sauvignon, in an endeavour to reduce vegetative growth and the source : sink ratio, to stimulate metabolic activity and to improve canopy microclimate, induced higher photosynthetic effectivity of the remaining leaves as well as an increase in assimilate supply to the bunches (Hunter \& Visser, 1988a; 1988b). The basal leaves, in particular, were found to be very important in fruit development during the entire growth season. Demand for assimilates, leaf age, and a suitable microclimate seemed to be of the utmost importance for maximum photosynthetic capacity. According to Kriedemann (1977), genetic factors primarily limit photosynthetic capacity by their effects on overall demand for photosynthetates and partitioning of assimilates between vegetative and reproductive growth. The rate of photosynthesis and associated reactions, i.e. stomatal resistance and transpiration of grape-vine leaves, are affected by light intensity (Kriedemann, 1968; 1977; Smart, 1974a; Kliewer, 1980; Koblet, 1984), intermittent light (Kriedemann, 1968; Koblet, 1984), temperature (Kriedemann, 1968; 1977; Alleweldt, Eibach \& Rühl, 1982; Koblet, 1984; Sepúlveda \& Kliewer, 1986; Sepúlveda, Kliewer \& Ryugo, 1986), relative humidity (Sepúlveda \& Kliewer, 1986), $\mathrm{CO}_{2}$ and $\mathrm{O}_{2}$ concentrations (Kriedemann, 1968; 1977), leaf age (Kriedemann, 1968; 1977; Kriedemann, Kliewer \& Harris, 1970; Pandey \& Farmahan, 1977; Alleweldt et al., 1982; Koblet, 1984), moisture supply (Smart, 1974b; Hofäcker, 1976; Kriedemann, 1977; Alleweldt \& Rühl, 1982), seasonal patterns and crop load (Kriedemann, 1977).

Apart from ${ }^{14} \mathrm{C}$-translocation studies at different developmental stages (Hale \& Weaver, 1962; Quinlan \& Weaver, 1970; Koblet \& Perret, 1971; 1972; Koblet, 1975; 1977; De La Harpe, 1984; Hunter \& Visser, $1988 \mathrm{a} ; 1988 \mathrm{~b})$, the rate of photosynthesis of grape-vine leaves as affected by partial defoliation and developmental stage of the vine has only been sparsely investigated (Kriedemann, 1977; Pandey \& Farmahan, 1977; Hofäcker, 1978). Consequently, this investigation deals with the effect of partial defoliation, leaf position and developmental stage of the vine on the photosynthesis, stomatal resistance and transpiration of Vitis vinifera $\mathrm{L}$. cv. Cabernet Sauvignon.

\section{MATERIALS AND METHODS}

\section{Experimental vineyard}

Details of the experimental vineyard used were given by Hunter \& Visser (1988a).

\section{Experimental design}

The experiment was laid out as a completely randomised $3 \times 4 \times 4$ factorial design. The three factors were: defoliation treatments, applied to the whole vine $(0 \%$, $33 \%, 66 \%$ ); measurement of physiological and environmental factors at four positions on one shoot per vine (opposite and below the bunches; basal; middle; apical); and developmental stages (berry set, pea berry size, véraison, ripeness). The basal, middle and apical leaf positions were defined according to leaf number on the shoot. The measurements were done at each of the four developmental stages. There were nine replications, comprising one vine per plot, for each of the 48 treatment combinations. 


\section{Defoliation treatments}

The defoliation treatments were initiated from approximately one month after budding and consisted of removing the first leaf out of every three leaves (33\%) and removing the first two leaves out of every three leaves $(66 \%)$ starting at the basal end of the shoot. All shoots, including lateral shoots, were treated likewise. Defoliation percentages were maintained until each sampling stage, i.e. leaves emerging after the initial defoliations were removed in the same manner as described above at approximately monthly intervals.

\section{Measurements}

Rate of photosynthesis $\left(\mathrm{mg} \mathrm{CO} / \mathrm{dm}^{2} / \mathrm{h}\right)$, stomatal resistance $(\mathrm{s} / \mathrm{cm})$, rate of transpiration $\left(\mu \mathrm{g} \mathrm{H} \mathrm{H}_{2} \mathrm{O} / \mathrm{cm}^{2} / \mathrm{s}\right)$, photon flux density (PFD) $\left(\mathrm{W} / \mathrm{m}^{2}\right)$, percentage relative humidity and leaf temperature $\left({ }^{\circ} \mathrm{C}\right)$, were measured using an ADC portable photosynthesis meter (supplied by The Analytical Development Co. Ltd., England). The photosynthesis apparatus consisted of an infra-red $\mathrm{CO}_{2}$ analyser, a data logger, a Parkinson broad leaf chamber (volume $=16 \mathrm{~cm}^{3}$, area $=6,25 \mathrm{~cm}^{2}$ ), and an air supply unit (length of sample tube $=4 \mathrm{~m}$ ). Radiation was measured using a quantum sensor with filters providing response over $400 \mathrm{~nm}$ to $700 \mathrm{~nm}$. Being unknown, the maximum vapour pressure $\left(E_{\max }\right)$ was taken as two. The air flow rate through the open system was adjusted to $300 \mathrm{~cm}^{3} / \mathrm{min}$. Measurements were carried out between $10 \mathrm{~h} 30$ and $14 \mathrm{~h} 00$ on the day scheduled. The maximum ambient temperatures for the days scheduled at berry set, pea size, véraison and ripeness were $27,4^{\circ} \mathrm{C}, 23,0^{\circ} \mathrm{C}, 23,5^{\circ} \mathrm{C}$ and $21,2^{\circ} \mathrm{C}$, respectively.

\section{Statistical analyses}

A standard VORI factorial statistical software package was used to test significant differences among treatment means. The same program was used to determine correlation coefficients.

\section{RESULTS AND DISCUSSION}

Because no significant interactions between defoliation percentage and developmental stage of the vine were found for any of the leaf positions, only the main effects, namely defoliation percentage and developmental stage, were considered. The figures therefore depict either averages over stages or averages over defoliation treatments, while data over both factors were used to calculate the correlation coefficients provided in the table.

Rate of photosynthesis: The photosynthetic rates of Cabernet Sauvignon leaves, which ranged from $2,64 \mathrm{mg} \mathrm{CO}_{2} / \mathrm{dm}^{2} / \mathrm{h}$ to $14,09 \mathrm{mg} \mathrm{CO}_{2} / \mathrm{dm}^{2} / \mathrm{h}$ (Fig.'s. $1 \mathrm{a} \&$ b), are comparable to those found for other cultivars (Kriedemann, 1968; 1977; Wareing, Khalifa \& Treharne, 1968; Kriedemann \& Lenz, 1972; Hofäcker, 1976; 1978; Marini \& Marini, 1983; Tan \& Buttery, 1986).

Partial defoliation $(33 \%$ and $66 \%)$ in all cases stimulated the photosynthetic rate, generally increasing with an increase in the degree of defoliation (Fig. 1a). This is in general agreement with the findings of Hodgkinson (1974), Kriedemann (1977), Hofäcker (1978) and Hunter \& Visser (1988b). The apical leaves of all treatments displayed the highest rate of photosynthesis, which support other findings that young, actively grow- (a)

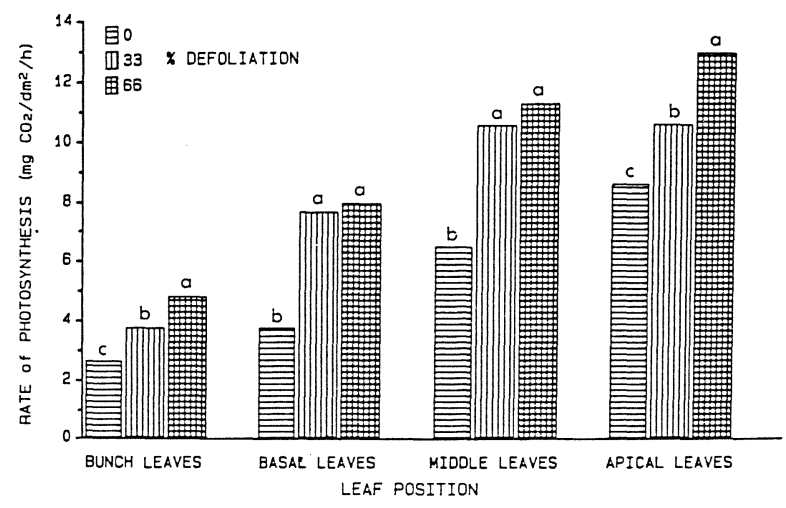

(b)

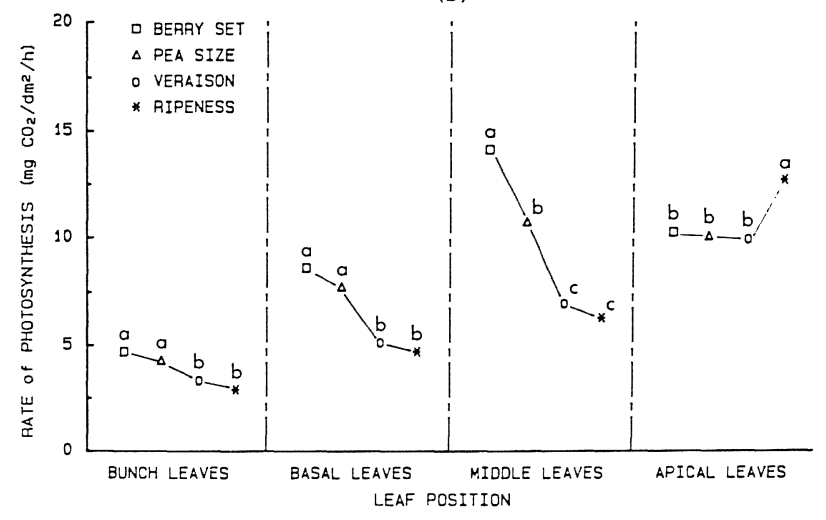

FIG. 1 a \& b

The effect of (a) defoliation, (b) developmental stage of the vine, and leaf position on the rate of photosynthesis of Cabernet Sauvignon leaves. Values designated by the same letter do not differ significantly $(p \leqslant 0,05)$ for each plant part.

ing leaves are largely photosynthetically self-sufficient (Kriedemann \& Lenz, 1972; Hunter \& Visser, 1988a). Evidently, the deeper into the canopy the leaves were situated, the more the rate of photosynthesis declined. Photosynthetic rate of the leaves opposite and below the bunches (bunch leaves) was very low, especially for the control vines ( $0 \%$ defoliation). This is also evident from Fig. 2, which shows the percentage photosynthetic rate of the bunch leaves, basal leaves, middle leaves and apical leaves in relation to the mean photosynthetic rate of all the leaves on the shoot for each defoliation treatment during the growth season. It seems that the

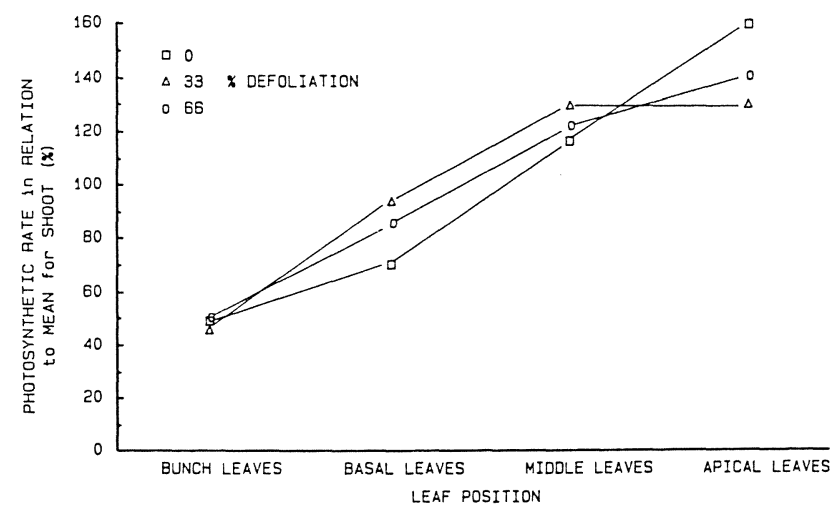

FIG. 2

The effect of defoliation on the percentage photosynthetic rate of leaves in different positions in relation to the mean photosynthetic rate of all the leaves on the shoot. 
percentage photosynthetic rate of the basal and middle leaves of the partially defoliated vines is higher than that of the control vines, but is noticeably lower than that of the control in the case of the apical leaves. Comparatively, the photosynthetic contribution of the bunch leaves in all cases was relatively low. This confirms the conclusion by Hunter \& Visser (1988a; 1988b) that the leaves opposite and below the bunches do not substantially contribute photosynthetates to the bunches.

These results support the concepts of other investigators that a dense canopy, receiving insufficient sunlight, is deleterious to the photosynthetic capacity of especially the interior leaves (Shaulis et al., 1966; Smart, 1973; 1974a; 1985; Kriedemann, 1977; Kliewer, 1980; Marini \& Marini, 1983; Koblet, 1984). However, demand for assimilates from vegetative as well as reproductive sinks could also have greatly increased with increasing degree of defoliation, causing the leaves on the partially defoliated vines to photosynthesize more actively. This would substantiate the findings of Kriedemann \& Lenz (1972), Hofäcker (1976; 1978) and Kriedemann (1977). According to Wareing, Khalifa \& Treharne (1968) competition among leaves for mineral nutrients as well as possibly hormones such as cytokinins, originating in the roots, might also contribute to an increased photosynthetic rate.

From Fig. 1b it is evident that rate of photosynthesis of the middle, basal and bunch leaves declined as the growth season progressed. Similar results were found

(a)

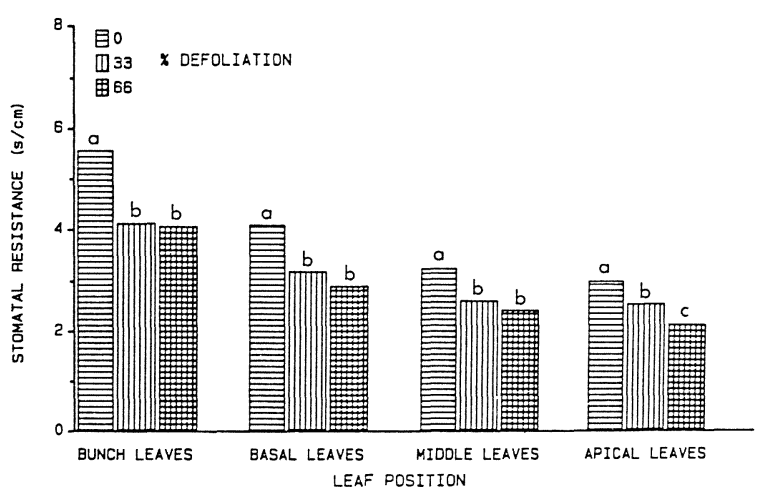

(b)

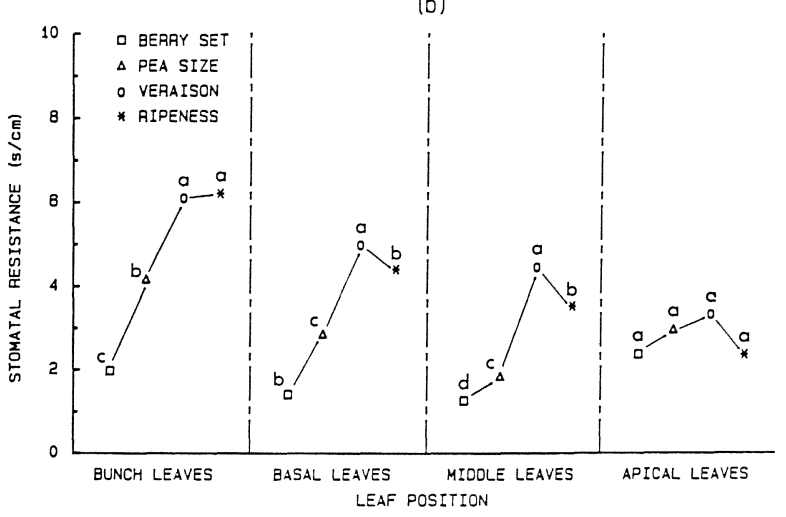

FIG. 3 a \& b

The effect of (a) defoliation, (b) developmental stage of the vine, and leaf position on the stomatal resistance of Cabernet Sauvignon leaves. Values designated by the same letter do not differ significantly $(p \leqslant 0,05)$ for each plant part. by Kriedemann (1977) and Hunter \& Visser (1988a; 1988 b). Possible reasons for this phenomenon were set out in the latter papers, i.e. an increasing senescence, an increase in sugar concentration, decreases in amino acids and organic acids and a decreased demand for assimilates from other sinks. The increase in photosynthetic rate of the apical leaves at ripeness corresponds to that found by Hunter \& Visser (1988a; 1988b).

Stomatal resistance: The stomatal resistance values, which vary from $1,24 \mathrm{~s} / \mathrm{cm}$ to $6,18 \mathrm{~s} / \mathrm{cm}$, are presented in Fig's. 3a \& b. These results are comparable to those found for other cultivars (Hofäcker, 1976; 1978; Sepúlveda \& Kliewer, 1986; Tan \& Buttery, 1986; Van Zyl, 1986).

Lowest stomatal resistance was found for the apical leaves in all cases (Fig. 3a). These values correspond to the $2 \mathrm{~s} / \mathrm{cm}$ to $3 \mathrm{~s} / \mathrm{cm}$ required for maximum rate of photosynthesis (Kriedemann, 1977), which was also verified in this investigation (Fig. 1a). Stomatal resistance of the control vines in all cases was highest, while the values generally decreased with increasing percentage defoliation. Similar results were obtained by Hofäcker (1978).

Although it would seem that stomatal resistance increased as the growth season progressed, peak resistances mostly occurred at véraison stage, with a decline thereafter (Fig. 3b).

Rate of transpiration: Values for the rate of transpiration, which ranged from $2,82 \mu \mathrm{g} \mathrm{H}_{2} \mathrm{O} / \mathrm{cm}^{2} / \mathrm{s}$ to $11,78 \mu \mathrm{g}$ $\mathrm{H}_{2} \mathrm{O} / \mathrm{cm}^{2} / \mathrm{s}$ (Fig's. $4 \mathrm{a} \& \mathrm{~b}$ ) compare well with those

(a)

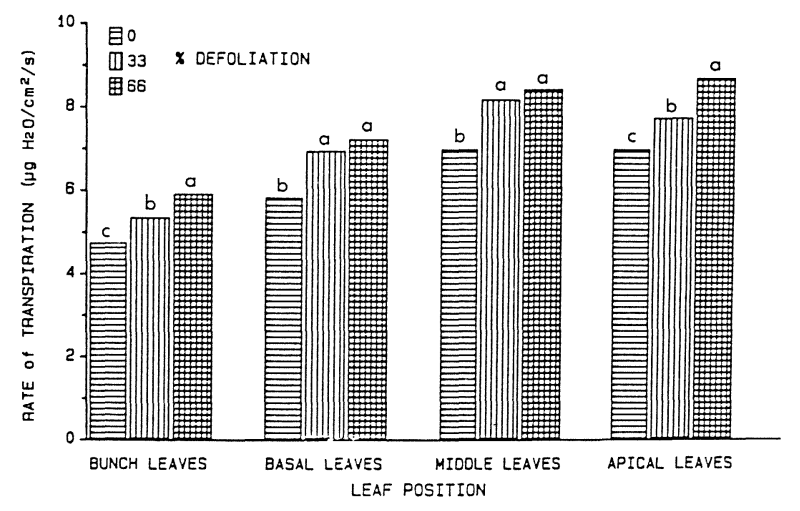

(b)

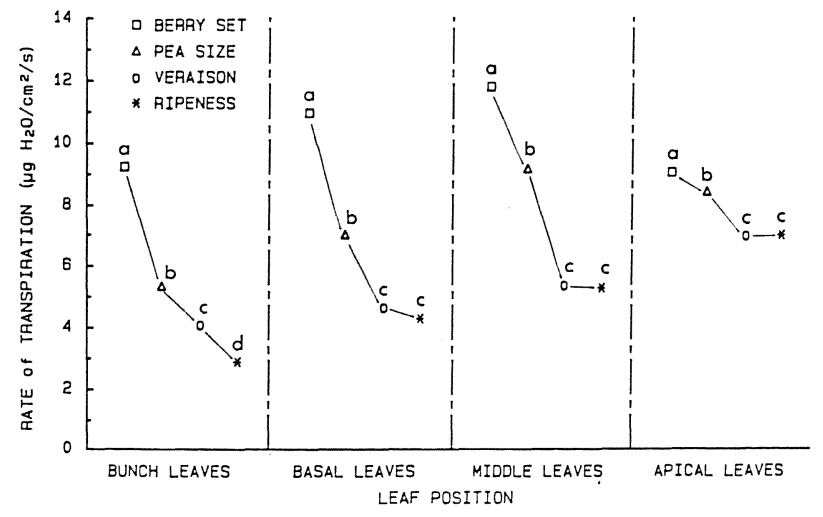

FIG. 4 a \& b

The effect of (a) defoliation, (b) developmental stage of the vine, and leaf position on the rate of transpiration of Cabernet Sauvignon leaves. Values designated by the same letter do not differ significantly $(p \leqslant 0,05)$ for each plant part. 
found by Smart (1974b) for the leaves of irrigated Shiraz vines. Similar to the rate of photosynthesis (Fig. 1a), transpiration rates generaily increased with an increase in degree of defoliation (Fig. 4a). Transpiration generally decreased the deeper into the canopy the leaves were situated. Similar results were reported by Fails, Lewis \& Barden (1982).

A general decline in transpiration rate occurred as the leaves aged during the course of the growth season (Fig. 4b). Similar to photosynthesis (Fig. 1b) and stomatal resistance (Fig. 3b), it would seem that transpiration did not change much from véraison to ripeness stage, except for the bunch leaves where it decreased sharply. The former can probably be explained by a recommencement of vegetative growth at ripeness stage as suggested by Hunter \& Visser (1988a; 1988b).

Transpiration : photosynthesis ratio: These ratios are given in Fig's. 5a \& b. It is evident that for all different leaf positions, the ratio tended to decline with increasing degree of defoliation (Fig. 5a). Although a concomitant increase in both photosynthesis (Fig. 1a) and transpiration (Fig. 4a) was found, the transpiration : photosynthesis ratio implies that $\mathrm{CO}_{2}$ was relatively more effectively utilized with increasing degree of defoliation. These results confirm the commonly observed more effective use of leaf area when the size of the source is reduced in relation to the size of the sinks (Buttrose, 1966; May et al., 1969; Kliewer \& Antcliff,

(a)
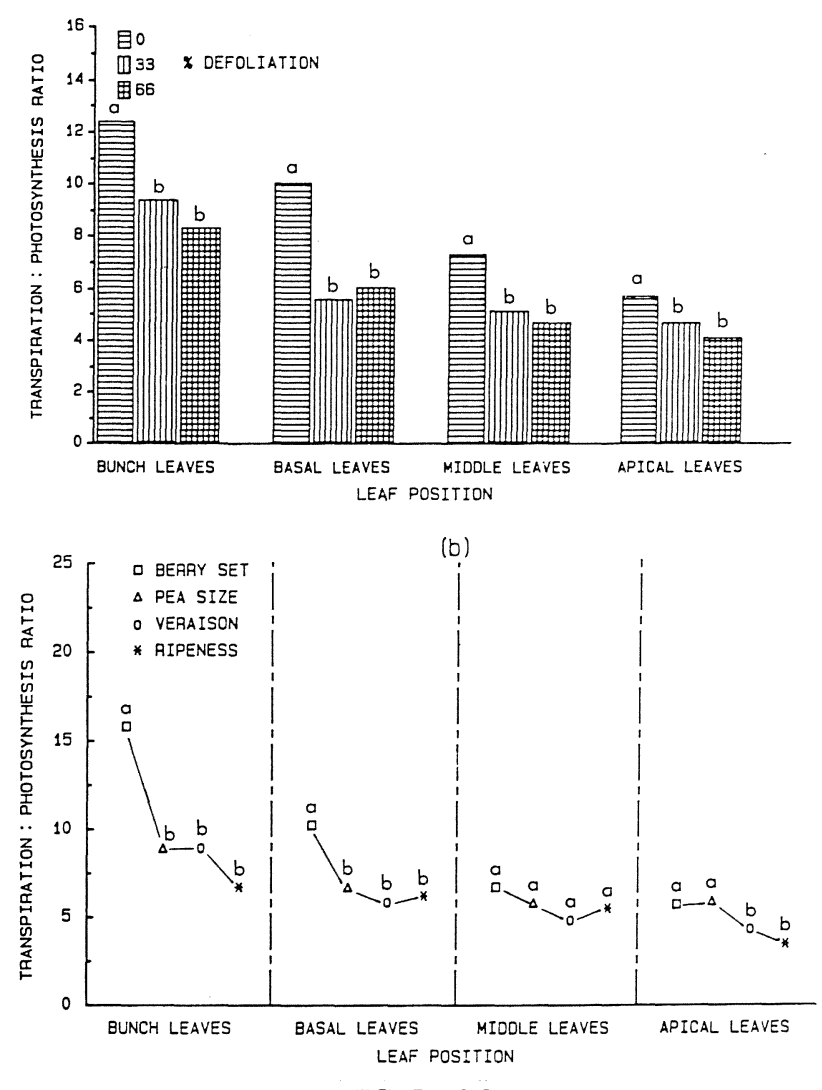

FIG. 5 a \& b

The effect of (a) defoliation, (b) developmental stage of the vine, and leaf position on the transpiration : photosynthesis ratio of Cabernet Sauvignon leaves. Values designated by the same letter do not differ significantly $(p \leqslant 0,05)$ for each plant part.
1970; Kriedemann, 1977; Hofäcker, 1978; Johnson, Weaver \& Paige, 1982). The ratio increased the deeper into the canopy the leaves were situated, verifying the well-known photosynthesis inhibiting effect of shade in the canopy interior.

Carbon dioxide was more effectively assimilated at ripeness than at berry set stage for all the leaves on the shoot (Fig. 5b). It would therefore seem that although the capacity to metabolize $\mathrm{CO}_{2}$, i.e. rate of photosynthesis (Fig. 1b), as well as transpiration (Fig. 4b) declined and stomatal resistance increased (Fig. 3b), $\mathrm{CO}_{2}$ exchange between the leaf interior and the atmosphere improves when leaves age. A better influx of $\mathrm{CO}_{2}$ could be due to the more open structure of the palisade and mesophyll tissues of mature or senescent foliage (Kriedemann et al., 1970) and to the decrease in selective permeability of membranes of aged leaves (Sacher, 1957).

Photon flux density: The photon flux density (PFD) values $\left(\mathrm{W} / \mathrm{m}^{2}\right)$ are given in Fig's. 6a \& b. The irradiance at the apical leaf position for non-defoliated vines corresponds to that needed for maximum photosynthetic rate of young grape-vine leaves, while those at the middle and basal leaf positions are in accordance with the findings for old leaves (Kriedemann, 1977). Evidently, sunlight penetration increased with increasing defoliation percentage (Fig. 6a). Definite light saturation responses occurred with increasing defoliation percentage from the basal to the apical leaf position. The PFD

(a)

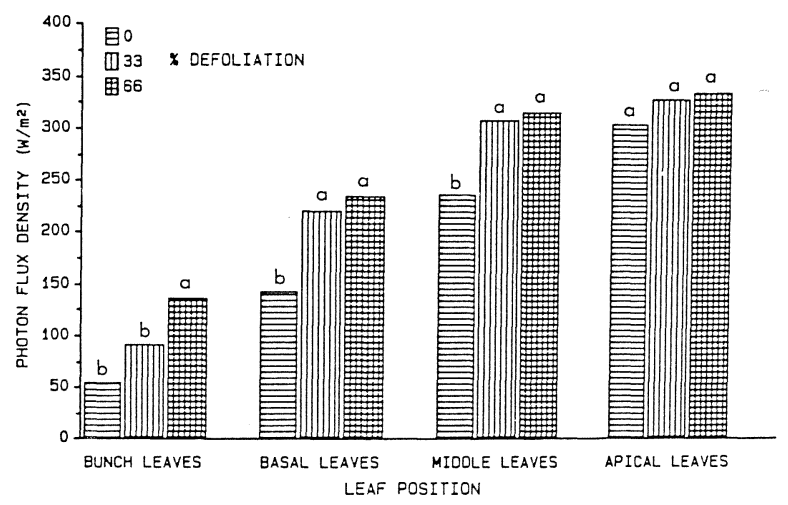

(b)

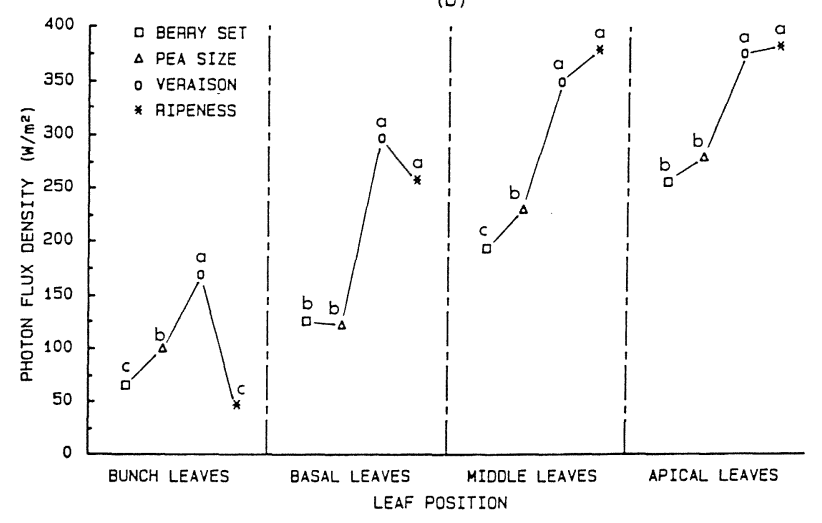

FIG. 6 a \& b

The effect of (a) defoliation and (b) developmental stage of the vine on the photon flux density in different leaf positions in the canopy of Cabernet Sauvignon. Values designated by the same letter do not differ significantly $(p \leqslant 0,05)$ for each plant part. 


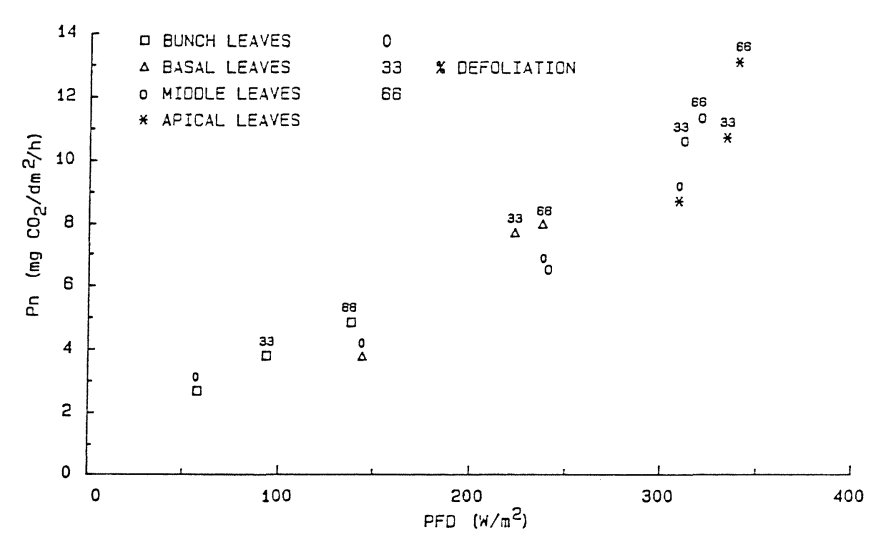

FIG. 7

The effect of defoliation and the response of photosynthesis (Pn) to increasing PFD levels at the different leaf positions.

levels for the apical leaves did not differ significantly between treatments, though there was a slight increase with increasing degree of defoliation. According to Smart (1974a) rate of photosynthesis depends on the total light flux density onto leaf surfaces, which can be direct and/or diffused light, with the former the main determinant in sunny climates. Since light intensity at the bunch leaf position is greatly reduced, the foregoing might explain the low rate of photosynthesis found for the bunch leaves (Fig. 1a \& b). Although the rate of photosynthesis of the bunch leaves and the basal leaves of the different defoliation treatments (Fig. 1a) corresponded to the PFD patterns, the photosynthesis of the middle leaves increased more than expected, while that of the apical leaves increased significantly. This finding suggests that the increase in photosynthetic rate of the apical leaves did not result solely from an improved microclimate, but rather from internal control, as was previously mentioned. This is also evident from Fig. 7, which shows the response of photosynthesis to increasing PFD levels at the different leaf positions. Regarding the corresponding negative relationship between PFD and stomatal resistance (Fig. 3a), Raschke (1975) found that stomata respond to light indirectly by responding to the reduction in $\mathrm{CO}_{2}$ concentration in the mesophyll as well as in the guard cells. Sheriff (1979) found that blue light is more effective than red light in causing stomatal opening or preventing stomatal closure. According to Smart, Smith \& Winchester (1987) leaves in the centre of dense canopies receive light of low flux density in the photosynthetic waveband of $400 \mathrm{~nm}$ to $700 \mathrm{~nm}$ and are also relatively enriched in the near infra red waveband. This might probably ex- (a)
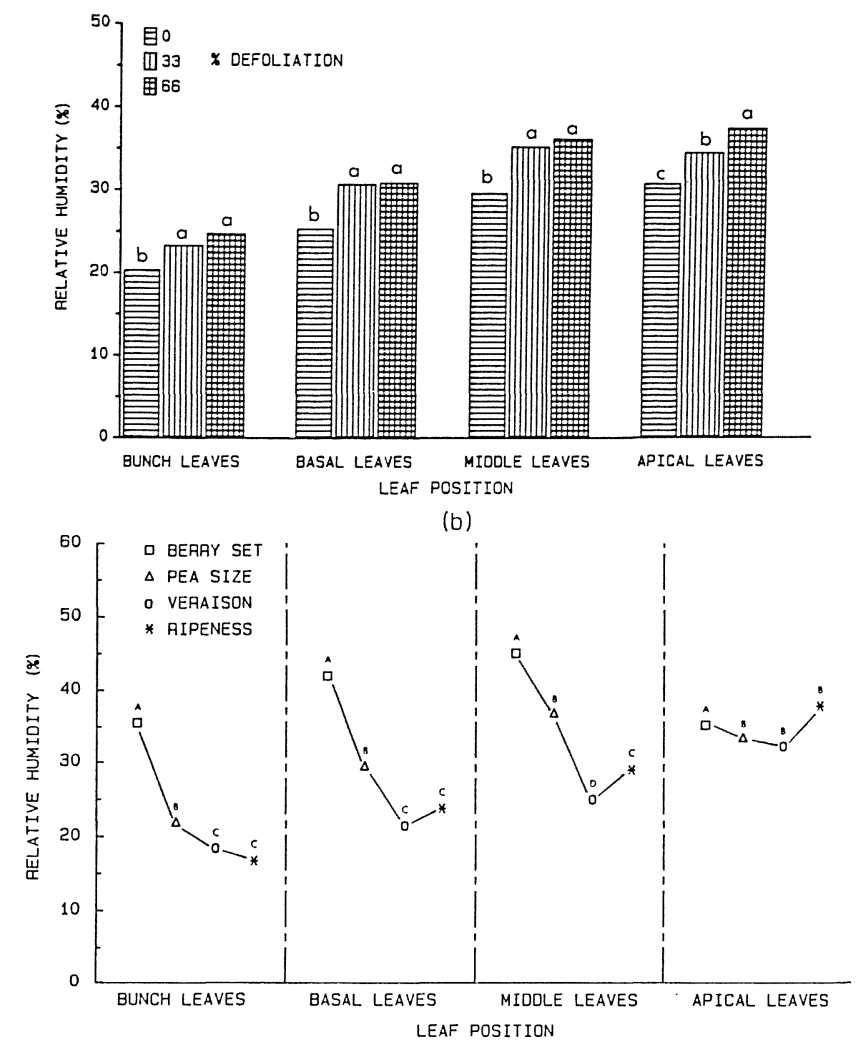

FIG. 8 a \& b

The effect of (a) defoliation, (b) developmental stage of the vine, and leaf position on the percentage relative humidity at the leaf surface of Cabernet Sauvignon. Values designated by the same letter do not differ significantly $(\mathrm{p} \leqslant 0,05)$ for each plant part.

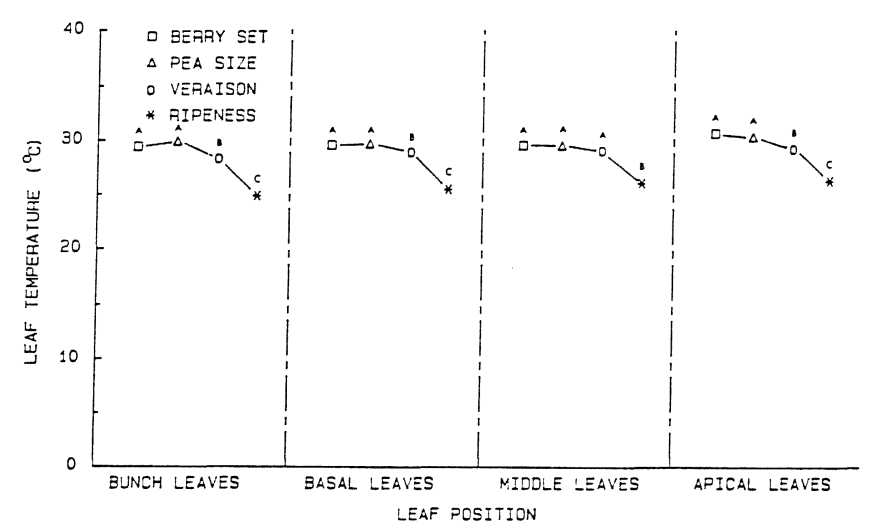

FIG. 9

The effect of developmental stage of the vine and leaf position on the temperature of Cabernet Sauvignon leaves. Values designated by the same letter do not differ significantly $(p \leqslant 0,05)$ for each plant part.

TABLE 1

Correlation coefficients ( $\mathrm{r}$ ) between the different parameters measured at different leaf positions on the shoot.

\begin{tabular}{|l|c|c|c|c|c|c|c|c|}
\hline & \multicolumn{2}{|l|}{ BUNCH LEAVES } & \multicolumn{2}{|l|}{ BASAL LEAVES } & MIDDLE LEAVES & APICAL LEAVES \\
\cline { 2 - 9 } INDEPENDENT VARIABLE & $\mathrm{r}_{\mathrm{s}}$ & $\mathrm{T}_{\mathrm{r}}{ }^{1)}$ & $\mathrm{r}_{\mathrm{s}}$ & $\mathrm{T}_{\mathrm{r}}$ & $\mathrm{r}_{\mathrm{s}}$ & $\mathrm{T}_{\mathrm{r}}$ & $\mathrm{r}_{\mathrm{s}}$ & $\mathrm{T}_{\mathrm{r}}$ \\
\hline Rate of Photosynthesis $(\mathrm{Pn})$ & $-0,70^{*}$ & $0,67^{*}$ & $-0,68^{*}$ & $0,73^{* *}$ & $-0,77^{* *}$ & $0,90^{* *}$ & $-0,84^{* *}$ & 0,38 \\
Stomatal Resistance $\left(\mathrm{r}_{\mathrm{s}}\right)$ & & $-0,93^{* *}$ & & $-0,91^{* *}$ & & $-0,92^{* *}$ & & $-0,67^{*}$ \\
\hline
\end{tabular}

1 Rate of transpiration ( $\mu \mathrm{g} \mathrm{H}_{2} \mathrm{O} / \mathrm{cm}^{2} / \mathrm{s}$ )

* Significantly correlated at $\mathrm{p} \leqslant 0,05$

** $\quad$ Significantly correlated at $p \leqslant 0,01$ 
plain the high stomatal resistance values found for especially the basal and bunch leaves of the non-defoliated vines in contrast to that of the partially defoliated vines.

The PFD for the apical and middle leaves increased as the growth season progressed, while no definite tendency for the basal and bunch leaves could be found (Fig. 6b). The increase in PFD at the first mentioned leaf positions possibly resulted from a more open canopy structure, created by the elongation and orientation of the shoots on the trellising system (data not shown). The indefinite tendency found for the basal and bunch leaves could be the result of overshadowing in the canopy-interior, creating irregular light conditions.

Percentage relative humidity: From Fig. $8 \mathrm{a}$ it is evident that percentage relative humidity at the leaf surface generally increased upon leaf removal. This probably resulted from the higher rate of transpiration (Fig. 4a), which also coincides with the general decline in humidity as the growth season progressed (Fig. 8b). The corresponding negative relationship of relative humidity with stomatal resistance (Fig. $3 a \&$ b) is in contrast to results obtained by Sepúlveda \& Kliewer (1986) with Cardinal, Chardonnay and Chenin blanc vines. Although humidity was measured at the leaf surface, the decrease towards the centre of the canopy is in contrast to the concept of Smart (1985), namely that transpiration by leaves and perhaps fruits can cause humidity build-up in the centre of a dense canopy.

Leaf temperature : No significant differences in leaf temperature $\left({ }^{\circ} \mathrm{C}\right)$ between defoliation treatments could be found (data not shown). The higher transpiration rates found for the partial defoliation treatments (Fig. 4a) possibly exerted a stabilizing effect on the leaf temperatures, thereby preventing it from rising as would be expected. Leaf temperatures, which ranged from $24,7^{\circ} \mathrm{C}$ to $30,7^{\circ} \mathrm{C}$ during the growth season, exhibited a general decrease towards the end of the growth season (Fig. 9). The temperature regime during the investigation approximated that needed for optimum photosynthesis (Kriedemann, 1977; Alleweldt et al., 1982; Koblet, 1984).

Correlation coefficients : In order to determine the relationship between rate of photosynthesis, stomatal resistance, and rate of transpiration, correlation coefficients were calculated (Table 1). Significant correlations between photosynthesis, transpiration and stomatal resistance were found for all leaf positions, except for the apical leaves in which case the former two were poorly correlated. According to Raschke (1975) a lack of proportionality between $\mathrm{CO}_{2}$ exchange and transpiration may result from the saturating effect of intercellular $\mathrm{CO}_{2}$ concentration on assimilation. Tan \& Buttery (1986) found a close relationship between rate of photosynthesis and stomatal conductance over a range of light levels as well as temperatures. Cowan (1972) also found stomatal oscillations to affect the ratios between $\mathrm{CO}_{2}$ assimilation and transpiration, which may optimize the relationship between assimilation and growth. However, Downton, Grant \& Loveys (1987), Farquhar \& Sharkey (1982) and Hodgkinson (1974) stated that stomatal movements only marginally limit the rate of $\mathrm{CO}_{2}$ assimilation. Hodgkinson (1974) concluded that the resistance to $\mathrm{CO}_{2}$ transfer between the intercellular spaces and fixation sites in the chloroplasts exerted the greatest effect on photosynthetic rates. $\mathrm{Al}$ though photosynthetic $\mathrm{CO}_{2}$ assimilation is greatly dependent on stomatal conductance under natural, ambient $\mathrm{CO}_{2}$ concentrations, Lange, Führer \& Gebel (1986) also found an independence of stomatal conductance under saturating $\mathrm{CO}_{2}$ partial pressures. The factors controlling non-stomatal limited $\mathrm{CO}_{2}$ assimilation are, however, still to be established (Lange, Tenhunen \& Beyschlag, 1985).

\section{CONCLUSIONS}

Photosynthetic rate of the partially defoliated vines was higher than that of the non-defoliated vines, generally increasing with degree of defoliation. Apart from the poorer microclimate, the sink capacity of the nondefoliated vines apparently did not weigh up to the source capacity. Therefore, feedback inhibition by assimilates and/or $\mathrm{CO}_{2}$ at the carboxylation sites in the mesophyll might also have occurred, inhibiting the rate of photosynthesis.

The apical leaves in all cases displayed the highest rate of photosynthesis, while the leaves opposite and below the bunches exhibited low photosynthetic rates, especially at véraison and ripeness stage. Photosynthetic contribution of the leaves of all defoliation treatments decreased as they were progressively situated deeper into the canopy. Therefore, as often occurs, measurements of the photosynthetic activities of interior-canopy leaves alone can lead to an underestimation of the photosynthetic capacity of the vine. More equally distributed photosynthetic rates in the canopies of the partially defoliated vines were found, especially in the region above the bunches.

A general decline in the rate of photosynthesis occurred as the growth season progressed and the leaves aged. It would seem that apical regrowth took place at ripeness stage.

Generally, tendencies of stomatal resistance and transpiration rate coincided with that found for rate of photosynthesis. However, the latter two correlated poorly for the apical leaves, suggesting that photosynthetic acitivity in that case was internally controlled. The transpiration : photosynthesis ratios might suggest a more effective utilization of $\mathrm{CO}_{2}$ for the partially defoliated vines.

Photon flux density and percentage relative humidity at the leaf surface increased upon partial defoliation, while leaf temperature showed no definite tendency. In general, tendencies of photon flux density and relative humidity related well to photosynthesis, stomatal resistance and transpiration of the leaves at all different leaf positions.

The results of this investigation suggest that excess vegetative growth is detrimental not only to interiorcanopy microclimate, but also to the photosynthetic rate of the entire vine. Partial defoliation seems to be an appropriate means of reducing the deleterious effects of vigorous growth on some physiological parameters

\section{LITERATURE CITED}

ALLEWELDT, G. \& RÜHL, E., 1982. Investigations on gas ex change in grape-vine II. Influence of extended soil drought on performance of several grape-vine varieties. Vitis 21, 313-324. 
ALLEWELDT, G., EIBACH, R. \& RÜHL, E., 1982. Investigations on gas exchange in grape-vine I. Influence of temperature, leaf age and daytime on net photosynthesis and transpiration. $\mathrm{Vi}$ tis 21, 93-100.

BUTTROSE, M.S., 1966. The effect of reducing leaf area on the growth of roots, stems and berries of Gordo grape-vines. Vitis $\mathbf{5}$, 455-464.

COWAN, I.R., 1972. Oscillations in stomatal conductance and plant functioning associated with stomatal conductance : Observations and a model. Planta 106, 185-219.

DE LA HARPE, A.C., 1984. The effect of summer pruning on growth and grape composition of Vitis vinifera L. cv. Cape Riesling. Ph.D.-thesis, University of Stellenbosch, 7600 Stellenbosch, Republic of South Africa.

DOWNTON, W.J.S., GRANT, W.J.R. \& LOVEYS, B.R., 1987. Diurnal changes in the photosynthesis of field-grown grapevines. New Phytol. 105, 71-80.

FAILS, B.S., LEWIS, A.J. \& BARDEN, J.A., 1982. Net photosynthesis and transpiration of sun- and shade-grown Ficus benjamina leaves. J. Amer. Soc. Hort. Sci. 107, 758-761.

FARQUHAR, G.D. \& SHARKEY, T.D., 1982. Stomatal conductance and photosynthesis. Ann. Rev. Plant Physiol. 33, 317-345.

HALE, C.R. \& WEAVER, R.J., 1962. The effect of developmental stage on direction of translocation of photosynthate in Vitis vinifera. Hilgardia 33, 89-131.

HODGKINSON, K.C., 1974. Influence of partial defoliation on photosynthesis, photorespiration and transpiration by lucerne leaves of different ages. Aust. J. Plant Physiol. 1, 561-578.

HOFÄCKER, W., 1976. Investigations on the influence of changing soil water supply on the photosynthesis intensity and the diffusive resistance of vine leaves. Vitis 15, 171-182.

HOFÄCKER, W., 1978. Investigations on the photosynthesis of vines. Influence of defoliation, topping, girdling and removal of grapes. Vitis 17, 10-22.

HUNTER, J.J. \& VISSER, J.H., 1988a. Distribution of ${ }^{14} \mathrm{C}$-Photosynthetate in the shoot of Vitis vinifera L. cv Cabernet Sauvignon. I. The effect of leaf position and developmental stage of the vine. S. Afr. J. Enol. Vitic. 9, 3-9.

HUNTER, J.J. \& VISSER, J.H., 1988b. Distribution of ${ }^{14}$ C-Photosynthetate in the shoot of Vitis vinifera L. cv Cabernet Sauvignon. II. The effect of partial defoliation. S. Afr. J. Enol. Vitic. 9, $10-15$.

JOHNSON, J.O., WEAVER, R.J. \& PAIGE, D.F., 1982. Differences in the mobilization of assimilates of Vitis vinifera L. grapevines as influenced by an increased source strength. Am. J. Enol. Vitic. 33, 207-213.

KLIEWER, W.M., 1980. Vineyard canopy management - a review, 342-352, Grape and Wine Centennial Symp. Proc. University of California, Davis.

KLIEWER, W.M. \& ANTCLIFF, A.J., 1970. Influence of defoliation, leaf darkening and cluster shading on the growth and composition of Sultana grapes. Am. J. Enol. Vitic. 21, 26-36.

KOBLET, W., 1975. Wanderung von Assimilaten aus verschiedenen Rebenblättern während der Reifephase der Trauben. WeinWiss. 30, 241-249.

KOBLET, W., 1977. Translocation of photosynthate in grape-vines. In : Proc. Int. Symp. on the Quality of the Vintage, 14-21 Feb. Cape town, pp. 45-51.

KOBLET, W., 1984. Influence of light and temperature on vine performance in cool climates and applications to vineyard management. In : Heatherbell, D.A., Lombard, P.B., Bodyfelt, F.W. \& Price, S.F. (eds.). Proc. Int. Symp. on Cool Climate Vitic. Enol. Oregon State University, Oregon, pp. 139-157.

KOBLET, W. \& PERRET, P., 1971. Kohlehydratwanderung in Geiztrieben von Reben. Wein-Wiss. 26, 202-211.

KOBLET, W. \& PERRET, P., 1972. Wanderung von Assimilaten innerhalb der Rebe. Wein-Wiss. 27, 146-154.

KRIEDEMANN, P.E., 1968. Photosynthesis in vine leaves as a function of light intensity, temperature, and leaf age. Vitis $\mathbf{7}$, 213-220.

KRIEDEMANN, P.E., 1977. Vineleaf photosynthesis. In : Proc. Int. Symp. on the Quality of the Vintage, 14-21 Feb. Cape Town, pp. 67-87.

KRIEDEMANN, P.E. \& LENZ, F., 1972. The response of vineleaf photosynthesis to shoot tip excision and stem cincturing. Vitis 11, 193-197.
KRIEDEMANN, P.E., KLIEWER, W.M. \& HARRIS, J.M., 1970. Leaf age and photosynthesis in Vitis vinifera L. Vitis 9, 97-104.

LANGE, O.L., FÜHRER, G. \& GEBEL, J., 1986. Rapid field determination of photosynthetic capacity of cut spruce twigs (Picea abies) at saturating ambient $\mathrm{CO}_{2}$. Trees $1,70-77$.

LANGE, O.L., TENHUNEN, J.D. \& BEYSCHLAG, W., 1985. Effects of humidity during diurnal courses on the $\mathrm{CO}_{2}$ - and lightsaturated rate of net $\mathrm{CO}_{2}$ uptake in the sclerophyllous leaves of Arbutus unedo. Oecologia, 67, 301-304.

MARINI, R.P. \& MARINI, M.C., 1983. Seasonal changes in specific leaf weight, net photosynthesis, and chlorophyll content of peach leaves as affected by light penetration and canopy position. J. Am. Soc. Hort. Sci. 108, 600-605.

MAY, P., SHAULIS, N.J. \& ANTCLIFF, A.J., 1969. The effect of controlled defoliation in the Sultana vine. Am.J. Enol. Vitic. 20, 237-250.

PANDEY, R.M. \& FARMAHAN, H.L., 1977. Changes in the rate of photosynthesis and respiration in leaves and berries of Vitis vinifera grape-vines at various stages of berry development. Vitis 16, 106-111.

QUINLAN, J.D. \& WEAVER, R.J., 1970. Modification of pattern of the photosynthate movement within and between shoots of $\mathrm{Vi}$ tis vinifera L. Plant Physiol. 46, 527-530.

RASCHKE, K., 1975. Stomatal action. Ann. Rev. Plant Physiol. 26, 309-340.

SACHER, J.A., 1957. Relationship between auxin and membraneintegrity in tissue senescence and abscission. Science 125, 1199-1200.

SHAULIS, N.J., AMBERG, H. \& CROWE, D., 1966. Response of Concord grapes to light, exposure and Geneva double curtain training. Am. Soc. Hort. Sci. 89, 268-280.

SHAULIS, N.J. \& MAY, P., 1971. Response of Sultana vines to training on a divided canopy and to shoot crowding. Am. J. Enol. Vitic. 22, 215-222.

SEPÚLVEDA, G. \& KLIEWER, W.M., 1986. Stomatal response of three grape-vine cultivars (Vitis vinifera $\mathrm{L}$.) to high temperature. Am. J. Enol. Vitic. 37, 44-52.

SEPÚLVEDA, G., KLIEWER, W.M. \& RYUGO, K., 1986. Effect of high temperature on grape-vines (Vitis vinifera L.) I. Translocation of ${ }^{14} \mathrm{C}$-photosynthates. Am. J. Enol. Vitic. 37, 13-19.

SHERIFF, D.W., 1979. Stomatal aperture and the sensing of the environment by guard cells. Plant, Cell and Environment 2, 15-22.

SMART, R.E., 1973. Sunlight interception by vineyards. Am. J. Enol. Vitic. 24, 141-147.

SMART, R.E., 1974a. Photosynthesis by grape-vine canopies. J. Appl. Ecol. 11, 997-1006.

SMART, R.E., 1974b. Aspects of water relations of the grape-vine (Vitis vinifera). Am. J. Enol. Vitic. 25, 84-91.

SMART, R.E., 1980. Vine manipulation to improve wine grape quality, 362-375, Grape and Wine Centennial Symp. Proc. University of California, Davis.

SMART, R.E., SHAULIS, N.J. \& LEMON, E.R., 1982. The effect of Concord vineyard microclimate on yield II. The interrelationships between microclimate and yield expression. Am. J. Enol. Vitic. 33, 109-116.

SMART, R.E., 1985. Principles of grape-vine canopy microclimate manipulation with implications for yield and quality. A review. Am. J. Enol. Vitic. 36, 230-239.

SMART, R.E., ROBINSON, J.B., DUE, G.R. \& BRIEN, C.J., 1985a. Canopy microclimate modification for the cultivar Shiraz I. Definition of canopy microclimate. Vitis 24, 17-31.

SMART, R.E., ROBINSON, J.B., DUE, G.R. \& BRIEN, C.J., 1985b. Canopy microclimate modification for the cultivar Shiraz II. Effects on must and wine composition. Vitis 24, 119-128.

SMART, R.E., SMITH, S.M. \& WINCHESTER, R.V., 1987. Light quality and quantity effects on fruit ripening for Cabernet Sauvignon. Am. J. Enol. Vitic. Submitted for publication.

TAN, C.S. \& BUTTERY, B.R., 1986. Photosynthesis, stomatal conductance, and leaf water potential in response to temperature and light in peach. Hort. Science 21, 1180-1182.

VAN ZYL, J.L., 1986. Canopy temperature as a water stress indicator in vines. S. Afr. J. Enol. Vitic. 7, 53-60.

WAREING, P.F., KHALIFA, M.M. \& TREHARNE, K.J., 1968. Rate-limiting processes in photosynthesis at saturating light intensities. Nature 220, 453-457. 